Primljen / Received: 3.7.2012.

Ispravljen / Corrected: 15.1.2013.

Prihvaćen / Accepted: 20.1.2013.

Dostupno online / Available online: 15.2.2013.

\section{Contribution to the study of recycled asphalt aggregate mixes}

Authors:

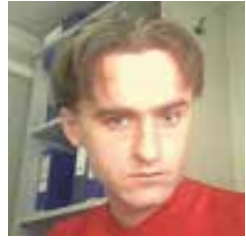

Ivica Androjić

Osijek-Koteks d.d.

ivica.androjic@osijek-koteks.hr

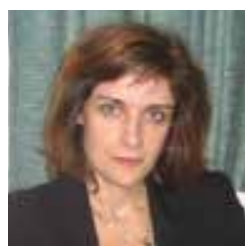

Prof. Sanja Dimter, PhD. CE

University J.J. Strossmayer of Osijek

Faculty of Civil Engineering

sdimter@gfos.hr
Ivica Androjič, Sanja Dimter

Professional paper

\section{Contribution to the study of recycled asphalt aggregate mixes}

Possibilities for using recycled asphalt in the asphalt mix manufacturing process are described in the paper. The applicability of recycled asphalt was tested in laboratory, and asphalt mixes BNHS-22 containing $10 \%, 15 \%$ and $20 \%$ of recycled asphalt were designed. The trial production of asphalt mixes designed in this way was then operated. The results obtained have lead to conclusions about the applicability and necessary proportion of recycled asphalt, manufacturing technology, and possible savings in the manufacture of new asphalt mixes.

Key words:
recycled asphalt, asphalt mix, production technology, cost savings

Stručni rad

Ivica Androjić, Sanja Dimter

\section{Prilog istraživanju mješavina s recikliranim asfaltnim agregatom}

U radu su opisana ispitivanja mogućnosti primjene recikliranog asfalta u proizvodnji asfaltnih mješavina. Ispitivanjima u laboratoriju istražena je pogodnost za primjenu recikliranog asfalta te projektiran sastav asfaltnih mješavina BNHS-22 s 10\%, 15\% i 20\% recikliranog asfalta nakon čega je izvedena pokusna proizvodnja projektiranih asfaltnih mješavina. Dobiveni rezultati omogućili su donošenje zaključaka o primjenjivosti i potrebnom udjelu recikliranog asfalta, tehnologiji proizvodnje te mogućim uštedama u proizvodnji novih asfaltnih mješavina.

Ključne riječi:

reciklirani asfalt, asfaltne mješavine, tehnologija proizvodnje, uštede

Fachbericht

Ivica Androjić, Sanja Dimter

\section{Verwendung von rezyklierten Gesteinskörnungen in Asphaltmischungen}

In der vorliegenden Arbeit ist die mögliche Anwendung von rezykliertem Asphalt in der Herstellung von Asphaltmischungen erforscht. Durch experimentelle Versuche in Laborbedingungen ist die Eignung von rezykliertem Asphalt für Asphaltmischungen untersucht und die Zusammensetzung von BNHS-22 Mischungen mit 10\%, 15\% und 20 $\%$ rezykliertem Asphalt entworfen worden. Anschließend ist eine Versuchsherstellung der zusammengestellten Asphaltmischungen durchgeführt worden. Die erhaltenen Ergebnisse haben Schlussfolgerungen bezüglich der Verwendbarkeit von rezykliertem Asphalt, der erforderlichen Mischungsanteile, der Fertigungstechnik und der möglichen Einsparungen im Herstellungsprozess von neuen Asphaltmischungen ermöglicht.

Schlüsselwörter:

rezyklierter Asphalt, Asphaltmischungen, Fertigungstechnik, Einsparungen 


\section{Introduction}

The sustainable development concept, adopted by the Republic of Croatia as the determinant of its future development [1], calls for protection of human environment and for preservation and protection of non-renewable sources of natural aggregates.

Although the Republic of Croatia ranks among countries with sufficient deposits of good-quality technical stone, the situation we have been faced with over the past several years has spurred some different thoughts and ideas about the sparing use and protection of good-quality materials for the construction and maintenance of roads. The costs of transport of stone material from the quarry to the place where the material is used have increased, and so have the costs of energy in quarries, and the price of bitumen. Strong demands for preservation of our environment have resulted in an increase in the price of stone aggregate, while also imposing the need to look for efficient and cost-effective procedures and alternative materials for the construction and maintenance of roads [2].

The reuse of old asphalt in the production of new asphalt mixes is certainly one of procedures that enable a more rational and environmentally friendly construction of new asphalt pavements. An internationally accepted name of recycled asphalt is the RAP (reclaimed asphalt pavement). It is the asphalt obtained by tearing, crushing or milling of the existing old asphalt pavement [3] that contains about 95 percent of good-quality and well graded bitumen-enveloped aggregate. The asphalt recycling has been practiced worldwide for many years now. First serious studies were conducted in the late 1970 s by the start of pilot projects in the USA, as a result of an increasing awareness of the need to recycle. There are several reasons why recycling was considered important at that time. The most significant one was the oil embargo which resulted in the steep increase in the price of bitumen and so it became important to find a way to use the old asphalt. In addition, development of mechanical milling machines that have replaced rippers and warming and scraping machines, and enabled milling without prior heating and pollution, has greatly contributed to a growing acceptance of recycling practices. Finally, the popularity of recycling procedures has also been increased by the development of drum mix facilities before which engineers had tried in vain to solve the issue of how to recycle in batch mix facilities [4].

The use of recycled asphalt in new mixes is nowadays considered as one of the most widespread uses of a waste material. In the USA, the asphalt ranks first in terms of reuse when compared to other alternative materials: more than 80 percent of old asphalt is actually reused. In Europe, the RAP is extensively used in Denmark, France, Sweden and Germany, and a specially interesting example is the Netherlands where the proportion of old asphalt in the production of asphalt mixes stands at 30 to 40 percent. In fact, the Netherlands is known as the country with the Europe's highest percentage of recycling of various waste materials. This comes from a high level of awareness about the value of our environmental, and from efforts that are continuously being made not to use the surrounding soil as dumping grounds for waste materials [2], and to avoid depletion of natural sources of materials.

The use of recycled asphalt offers various benefits and savings in the production of asphalt mixes. Nevertheless, care should be taken during mix design about the fact that we are dealing with material whose properties may significantly influence the properties of the new asphalt mix, especially due to bitumen binder. Properties of the recycled asphalt must carefully be tested and especially its content in the new asphalt mix, so that the properties of the resulting mix are similar to those of mixes that do not contain recycled asphalt. Laboratory tests conducted on recycled asphalt in order to obtain best properties of the resulting asphalt mix are presented below, together with trial production of designed asphalt mixes.

\section{Experimental analysis}

This analysis was conducted to determine suitability and necessary proportion of recycled asphalt in the new asphalt mix, in order to define the desired asphalt mix properties, and to make savings in the asphalt mix production.

\subsection{Testing properties of recycled asphalt}

The recycled asphalt used in the testing was obtained by mechanical milling of the existing asphalt pavement in a single layer, during rehabilitation of the national road D7 and county road $Z \mathbf{Z} 4202$ intersection in Vrpolje. The recycled asphalt tested and used for preparation of the trial mix design, and for trial production of asphalt mixes, is shown in Figure 1.

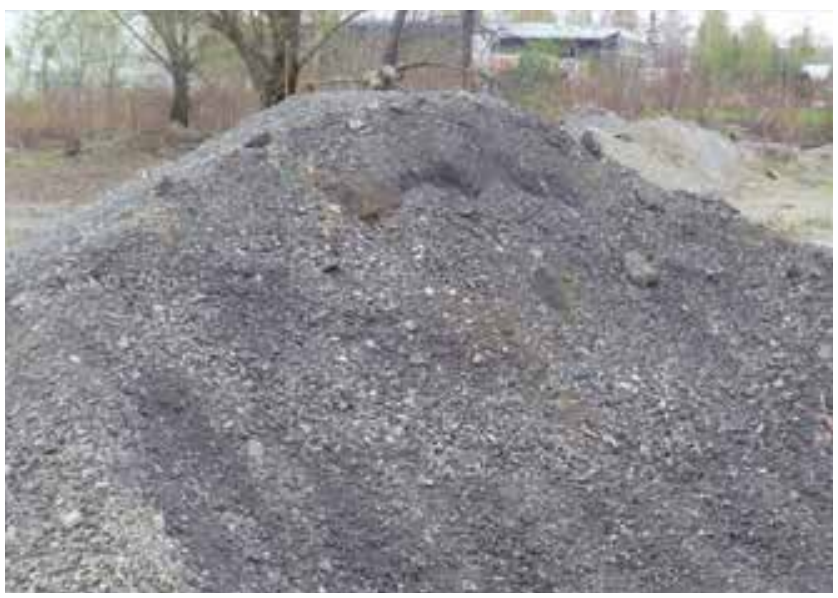

Figure 1. Recycled asphalt stockpile

The recycled asphalt mix grading shown in Figure 2 was determined according to HRN EN 12697-2 [5]. The grading diagram clearly points to significant deviations of the recycled 
asphalt mixes subjected to testing. This is due to mechanical milling of the existing asphalt pavement in a single layer. The total of four recycled asphalt mixes were tested. According to their grading [5], they can be classified into two groups: AB-11 and BNS-32. Preliminary laboratory tests of asphalt samples are based on the treatment of three recycled mixes which correspond, according to their grading, to the asphalt mix AB11. Subsequent sampling from the recycled mix conducted at the bottom of the stockpile at the asphalt plant, and the related laboratory analysis, have revealed that a part of the mix corresponds to the asphalt mix BNS-32.

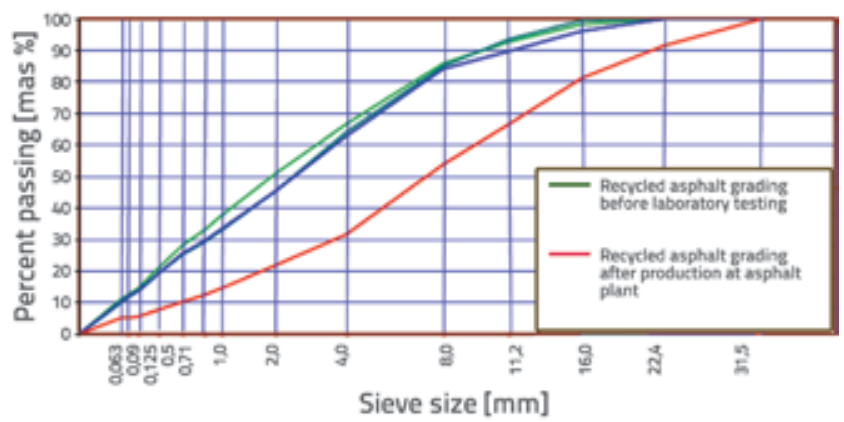

Figure 2. Grading of recycled asphalt mixes [5]

Numerical values for tested samples, i.e. mix grading and soluble part of paving bitumen determined as per HRN EN 12697-1 [6], are presented in Table 1. This table also shows minimum, maximum and mean values of individual components of recycled mix samples, and this during and after laboratory testing.

\subsection{Preparation of trial mix designs with recycled asphalt}

\subsubsection{Components for preparation of asphalt mixes}

The following materials were used in the preparation of asphalt mixes:

- rock flour (quarry: Hercegovac - Radlovac d.d.),

- stone chipping fractions $0 / 4,4 / 8,8 / 16,16 / 31.5$ (quarry: Hercegovac - Radlovac d.d.),

- paving bitumen 50/70 (MOL - Republic of Hungary),

- recycled asphalt mixes generated during rehabilitation of the D7 and Ž4202 road intersection in Vrpolje.

Three recycled asphalt mixes containing different proportions of paving bitumen $(5.2 \%, 5.50 \%$ and $6.10 \%)$ were tested in the scope of trial mix design in laboratory [6]. Based on results obtained by testing recycled asphalt mixes in laboratory, the grading with an optimum proportion of paving bitumen 50/70 $(4.90 \%)$ was designed, as shown in Table 2 .

The mix grading was determined by laboratory testing [5]. The density of asphalt samples was defined according to HRN EN 12697-5 [7], the density of asphalt mixes according to HRN EN 12697-6 [8], and the void content and the percent voids filled with asphalt according to HRN EN 12697-8 [9]. Limit values were specified according to applicable General technical

Table 1. Grading of recycled mix samples

\begin{tabular}{|c|c|c|c|c|c|c|c|c|c|c|c|c|c|c|c|}
\hline $\begin{array}{l}\text { Sieve } \\
{[\mathrm{mm}]}\end{array}$ & $\begin{array}{c}0,063 \\
{[\%]}\end{array}$ & $\begin{array}{c}0,09 \\
{[\%]}\end{array}$ & $\begin{array}{c}0,125 \\
{[\%]}\end{array}$ & $\begin{array}{c}0,25 \\
{[\%]}\end{array}$ & $\begin{array}{c}0,50 \\
{[\%]}\end{array}$ & $\begin{array}{l}0,71 \\
{[\%]}\end{array}$ & $\begin{array}{l}1,0 \\
{[\%]}\end{array}$ & $\begin{array}{l}2,0 \\
{[\%]}\end{array}$ & $\begin{array}{l}4,0 \\
{[\%]}\end{array}$ & $\begin{array}{l}8,0 \\
{[\%]}\end{array}$ & $\begin{array}{l}11,2 \\
{[\%]}\end{array}$ & $\begin{array}{l}16,0 \\
{[\%]}\end{array}$ & $\begin{array}{c}22,4 \\
{[\%]}\end{array}$ & $\begin{array}{c}31,5 \\
{[\%]}\end{array}$ & $\begin{array}{c}\text { Bitumen } \\
{[\%]}\end{array}$ \\
\hline $\begin{array}{l}\text { Mean } \\
\text { value }\end{array}$ & 9,40 & 10,70 & 12,30 & 17,10 & 22,80 & 26,40 & 30,10 & 41,20 & 56,70 & 77,80 & 86,30 & 94,30 & 98,40 & 100 & 5,03 \\
\hline $\begin{array}{c}\text { Minimum } \\
\text { values }\end{array}$ & 6,30 & 6,30 & 6,90 & 8,80 & 11,50 & 13,50 & 15,80 & 22,80 & 32,70 & 56,00 & 68,70 & 83,40 & 93,70 & 100 & 3,16 \\
\hline $\begin{array}{c}\text { Maximum } \\
\text { values }\end{array}$ & 11,10 & 12,70 & 14,60 & 21,00 & 28,40 & 33,10 & 37,70 & 50,80 & 66,80 & 86,00 & 93,50 & 99,50 & 100,0 & - & 6,05 \\
\hline
\end{tabular}

Table 2. Grading of the designed asphalt mix BNHS-22

\begin{tabular}{|c|c|c|c|c|c|c|c|c|c|c|c|c|c|c|}
\hline $\begin{array}{l}\text { Sieve } \\
{[\mathrm{mm}]}\end{array}$ & $\begin{array}{c}0,063 \\
{[\%]}\end{array}$ & $\begin{array}{l}0,09 \\
{[\%]}\end{array}$ & $\begin{array}{c}0,125 \\
{[\%]}\end{array}$ & $\begin{array}{c}0,25 \\
{[\%]}\end{array}$ & $\begin{array}{c}0,50 \\
{[\%]}\end{array}$ & $\begin{array}{r}0,71 \\
{[\%]}\end{array}$ & $\begin{array}{l}1,0 \\
{[\%]}\end{array}$ & $\begin{array}{l}2,0 \\
{[\%]}\end{array}$ & $\begin{array}{l}4,0 \\
{[\%]}\end{array}$ & $\begin{array}{l}8,0 \\
{[\%]}\end{array}$ & $\begin{array}{c}11,2 \\
{[\%]}\end{array}$ & $\begin{array}{l}16,0 \\
{[\%]}\end{array}$ & $\begin{array}{c}22,4 \\
{[\%]}\end{array}$ & $\begin{array}{c}\text { Bitumen } \\
{[\%]}\end{array}$ \\
\hline $\begin{array}{l}\text { Mean } \\
\text { value }\end{array}$ & 6,70 & 6,90 & 7,60 & 9,90 & 13,80 & 17,00 & 20,80 & 32,50 & 49,90 & 77,60 & 88,70 & 97,40 & 100,0 & 5,03 \\
\hline
\end{tabular}


requirements for road works, Volume III, Section 5-04. [10]. Mix design formulas, with $10 \%, 15 \%$ and $20 \%$ of recycled asphalt, were defined for asphalt mixes BNHS-22.

The grading of stone mix for the designed asphalt mix BNHS22 with $10 \%$ of recycled asphalt material in its composition is presented in Figure 3. The grading of stone mix for the designed asphalt mix with $15 \%$ of recycled asphalt material is presented in Figure 4. The grading of stone mix for the designed asphalt mix with $20 \%$ of recycled asphalt material is presented in Figure 5.

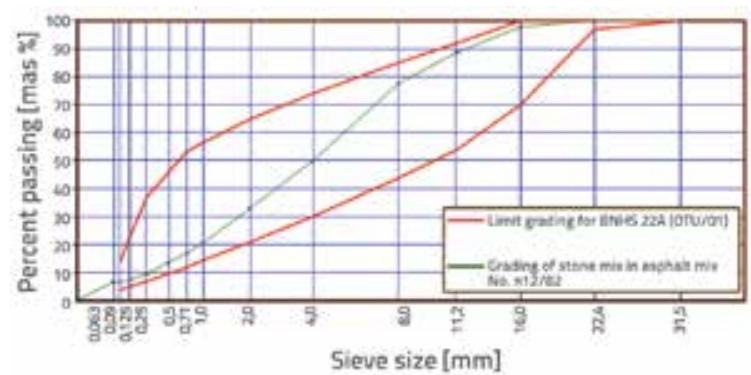

Figure 3. Grading of asphalt mix with $10 \%$ or recycled asphalt [5]

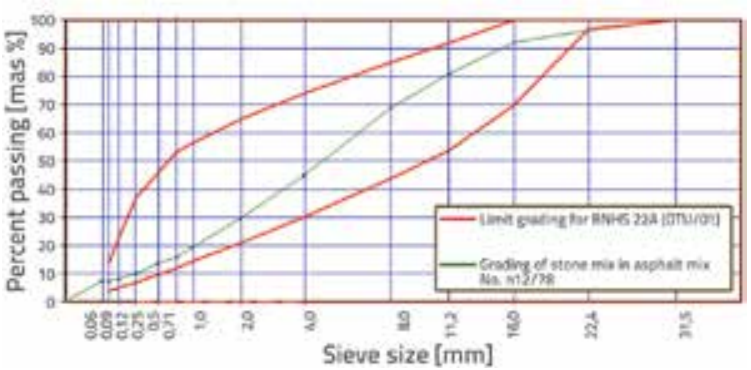

Figure 4. Grading of asphalt mix with $15 \%$ or recycled asphalt [5]

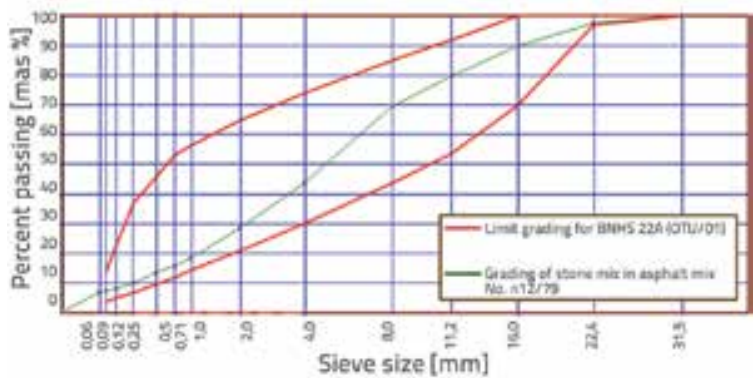

Figure 5 . Grading of asphalt mix with $20 \%$ or recycled asphalt [5]

Table 3. Results obtained by testing physicomechanical properties of mixes prepared in laboratory and mixes produced at the asphalt plant

\begin{tabular}{|c|c|c|c|c|c|c|c|c|}
\hline \multirow{2}{*}{$\begin{array}{l}\text { Sieves } \\
{[\mathrm{mm}]}\end{array}$} & \multicolumn{2}{|c|}{$10 \%$ recycled asphalt } & \multicolumn{2}{|c|}{$15 \%$ recycled asphalt } & \multicolumn{2}{|c|}{$20 \%$ recycled asphalt } & \multicolumn{2}{|c|}{$\begin{array}{l}\text { Requirements } \\
\text { as per GTR [10] }\end{array}$} \\
\hline & Laboratory & Plant & Laboratory & Plant & Laboratory & Plant & $\min$. & $\max$. \\
\hline 0,063 & 7,2 & 7,0 & 7,3 & 7,5 & 7,5 & 7,2 & & \\
\hline 0,090 & 7,9 & 7,2 & 7,9 & 7,5 & 8,2 & 7,3 & 4 & 14 \\
\hline 0,125 & 8,7 & 8,0 & 8,7 & 8,3 & 9,1 & 8,1 & & \\
\hline 0,250 & 10,2 & 10,4 & 10,4 & 10,2 & 11,0 & 10,2 & 7 & 37 \\
\hline 0,500 & 13,7 & 14,0 & 13,8 & 13,5 & 14,3 & 13,4 & & \\
\hline 0,710 & 15,8 & 16,9 & 15,9 & 16,0 & 16,5 & 15,7 & 12 & 53 \\
\hline 1,000 & 17,9 & 20,3 & 17,8 & 19,1 & 18,7 & 18,6 & & \\
\hline 2,000 & 26,0 & 31,1 & 25,3 & 29,5 & 26,5 & 28,6 & 21 & 65 \\
\hline 4,000 & 36,9 & 45,6 & 35,4 & 44,7 & 37,2 & 43,8 & 30 & 74 \\
\hline 8,000 & 57,1 & 68,8 & 56,6 & 68,8 & 58,6 & 69,5 & 44 & 85 \\
\hline 11,200 & 70,7 & 81,6 & 70 & 81,2 & 73,5 & 80,1 & 54 & 92 \\
\hline 16,000 & 89,7 & 88,6 & 89,9 & 92,3 & 90,9 & 89,9 & 70 & 100 \\
\hline 22,400 & 100,0 & 100 & 98,7 & 96,4 & 98,5 & 97,6 & 97 & 100 \\
\hline 31,500 & 100,0 & 100 & 100 & 100 & 100 & 100 & 100 & 100 \\
\hline Bitumen [\%] & 4,79 & 4,72 & 4,64 & 4,37 & 4,74 & 4,12 & 4,0 & 6,0 \\
\hline $\begin{array}{c}\text { Density of asphalt sample } \\
{\left[\mathrm{t} / \mathrm{m}^{3}\right]}\end{array}$ & 2525 & 2519 & 2521 & 2511 & 2515 & 2483 & & \\
\hline $\begin{array}{l}\text { Density of asphalt mix } \\
\qquad\left[\mathrm{t} / \mathrm{m}^{3}\right]\end{array}$ & 2631 & 2627 & 2641 & 2637 & 2626 & 2642 & & \\
\hline Void content [\%] & 4,03 & 4,11 & 4,54 & 4,78 & 4,13 & 6,02 & 2,0 & 5,0 \\
\hline Voids in stone mix [\%] & 15,89 & 15,77 & 16,01 & 15,54 & 15,91 & 16,05 & & \\
\hline $\begin{array}{l}\text { Voids filled with bitumen } \\
{[\%]}\end{array}$ & 74,64 & 73,43 & 71,62 & 69,24 & 73,44 & 62,50 & 70,0 & 86,0 \\
\hline
\end{tabular}




\subsubsection{Testing physicomechanical properties of asphalt mixes}

Comparison of results obtained by testing properties of mixes prepared in laboratory and mixes produced at the asphalt plant is given in Table 3. These results were compared with applicable requirements specified in General Technical Requirements for Road Works, Volume III [10].

Results shown in Table 3 reveal considerable deviations in mix grading and in soluble part of paving bitumen between laboratory asphalt mixes and mixes produced at the asphalt plant. Such considerable deviations are due to non-uniform composition of recycled mix, and to higher content of this mix in the manufactured asphalt mixes. The density of asphalt mixes varies from 2626 to $2642 \mathrm{t} / \mathrm{m}^{3}$. Manufactured asphalt mixes with $15 \%$ and $20 \%$ of recycled material in their composition have a lower percent voids filled with bitumen $(69.24 \%$ and $62.50 \%)$ when compared to [10]where at least 70 percent voids filled with bitumen is specified. The voids content in the asphalt mix with $20 \%$ of recycled material amounts to $6.02 \%$ which is also not compliant with [10] where the max. voids content is limited to $5.0 \%$.

\subsubsection{Trial production of asphalt mixes with recycled asphalt}

The laboratory testing was followed by trial production of the asphalt mix BNHS-22 containing different proportions of recycled asphalt ( $10 \%, 15 \%$ and $20 \%$ ). The total of $72 \mathrm{t}$ of asphalt mix was produced: 20 t with $10 \%$ of recycled asphalt, $26 t$ with $15 \%$ of recycled asphalt, and $26 \mathrm{t}$ with $20 \%$ of recycled asphalt. The trial production of the asphalt mix BNHS-22 with $10 \%$ of recycled asphalt is shown in Figure 6.

At the asphalt plant, the recycled asphalt proportioning was conducted without pre-heating, by direct proportioning into the mixer. Considering the operating principle applied at the plant, the mineral mix had to be heated to approx. $200^{\circ} \mathrm{C}$

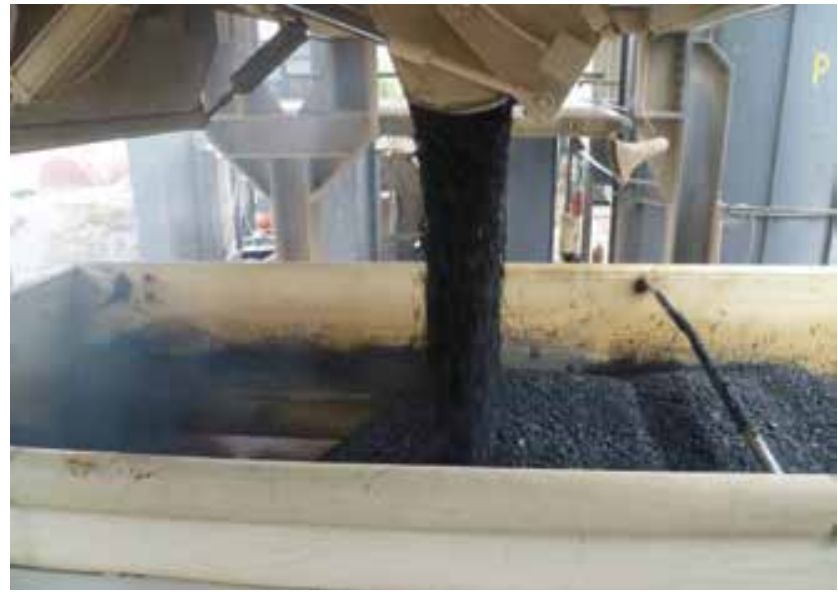

Figure 6. Trial production of asphalt mix with $10 \%$ of recycled asphalt which was determined in an arbitrary manner. The produced asphalt mix temperature of $145^{\circ} \mathrm{C}$ was controlled by means of a digital thermometer.

In order to produce the asphalt mix with $15 \%$ of recycled asphalt, the mineral mix had to be heated to $220^{\circ} \mathrm{C}$. The measured temperature of the produced asphalt mix amounted to $145^{\circ} \mathrm{C}$. The non-uniformity in mix composition was noted with regard to the recycled asphalt mix used. The recycled mix was mostly obtained by milling the bituminized base course with a lower content of paving bitumen which finally resulted in lower content of bitumen in the produced asphalt mix. These disadvantages have resulted in the reduction of savings in the paving bitumen proportioning, as shown in Table 5. It can be seen in Figure 7 that the proportioned recycled mix shown on the conveyor contains a number of stone grains from base courses of the pavement structure. Coarser grains were eliminated from the recycled asphalt mix at the $22 \mathrm{~mm}$ preliminary sieve.

In order to produce the asphalt mix with $20 \%$ of recycled asphalt, the mineral mix had to be heated to $235^{\circ} \mathrm{C}$. The measured temperature of the produced asphalt mix amounted to $144^{\circ} \mathrm{C}$. In the trial production of the asphalt mix with $20 \%$ of recycled asphalt, it was observed that the composition of the proportioned recycled material greatly deviates from previous laboratory testing results. The grading shown in Table 4 was established by subsequent laboratory testing of the recycled mix.

This grading shows considerable deviation with respect to previous three recycled mix samples tested. The proportion of paving bitumen in the tested sample amounted to 3.16 $\%$, which is much lower than the maximum tested value of $6.05 \%$.

The comparison of asphalt mixes with regard to proportion of recycled asphalt they contain, and the planned and actual savings in the components of the asphalt mix produced, are shown in Table 5. Actual savings in paving bitumen were considerably lower that the planned savings defined on the

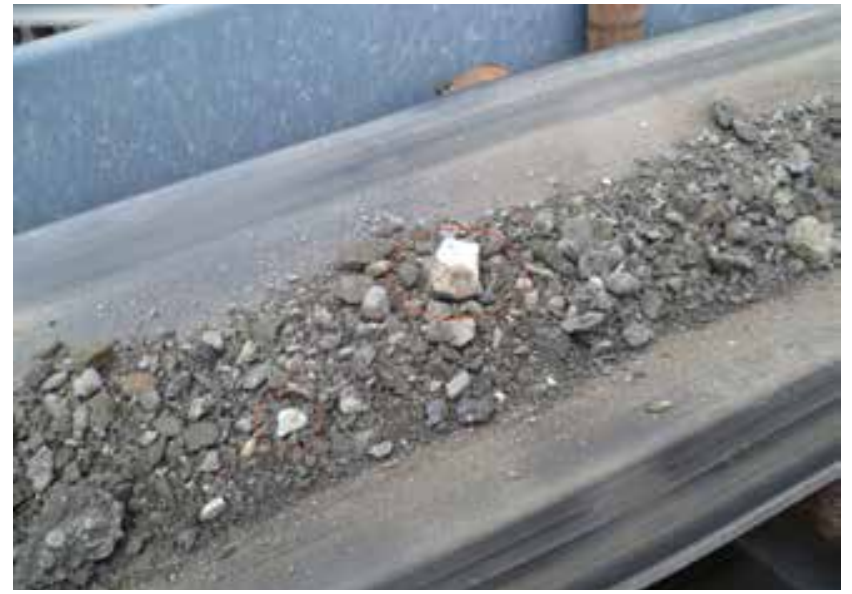

Figure 7. Recycled asphalt obtained by milling the bituminized base course 
Table 4. Recycled asphalt grading determined by subsequent testing [5]

\begin{tabular}{|c|c|c|c|c|c|c|c|c|c|c|c|c|c|c|}
\hline $\begin{array}{l}\text { Sieve } \\
{[\mathrm{mm}]}\end{array}$ & $\begin{array}{c}0,063 \\
{[\%]}\end{array}$ & $\begin{array}{c}0,09 \\
{[\%]}\end{array}$ & $\begin{array}{c}0,125 \\
{[\%]}\end{array}$ & $\begin{array}{c}0,25 \\
{[\%]}\end{array}$ & $\begin{array}{c}0,50 \\
{[\%]}\end{array}$ & $\begin{array}{c}0,71 \\
{[\%]}\end{array}$ & $\begin{array}{l}1,0 \\
{[\%]}\end{array}$ & $\begin{array}{l}2,0 \\
{[\%]}\end{array}$ & $\begin{array}{l}4,0 \\
{[\%]}\end{array}$ & $\begin{array}{l}8,0 \\
{[\%]}\end{array}$ & $\begin{array}{c}11,2 \\
{[\%]}\end{array}$ & $\begin{array}{c}16,0 \\
{[\%]}\end{array}$ & $\begin{array}{c}22,4 \\
{[\%]}\end{array}$ & $\begin{array}{c}\text { Bitumen } \\
{[\%]}\end{array}$ \\
\hline $\begin{array}{l}\text { Mean } \\
\text { value }\end{array}$ & 6,30 & 6,30 & 6,90 & 8,80 & 11,50 & 13,50 & 15,80 & 22,80 & 32,70 & 56,00 & 68,70 & 83,40 & 93,70 & 3,16 \\
\hline
\end{tabular}

Table 5. Planned and actual savings in the asphalt mixes produced

\begin{tabular}{|c|c|c|c|}
\hline $\begin{array}{c}\text { BNHS-22 } \\
\text { Bituminized base/wearing course }\end{array}$ & $10 \%$ recycled asphalt & $15 \%$ recycled asphalt & $20 \%$ recycled asphalt \\
\hline Savings realized in mineral mix & cca $11 \%$ & cca $19 \%$ & $23 \%$ \\
\hline $\begin{array}{c}\text { Expected proportion of paving bitumen before production, } \\
\text { based on laboratory testing }\end{array}$ & $4,90-5,10 \%$ & $4,80-5,00 \%$ & $4,00 \%$ \\
\hline $\begin{array}{c}\text { Planned savings in paving bitumen proportioning } \\
\text { Real savings in paving bitumen }\end{array}$ & $\begin{array}{c}5,20-6,00 \mathrm{~kg} / \mathrm{t} \\
(10,50-12,20 \%)\end{array}$ & $\begin{array}{c}7,80-9,10 \mathrm{~kg} / \mathrm{t} \\
(15,80-18,50 \%)\end{array}$ & $\begin{array}{c}10,40-12,10 \mathrm{~kg} / \mathrm{t} \\
(21,20-24,70 \%)\end{array}$ \\
\hline
\end{tabular}

basis of laboratory testing of recycled mix samples. This is explained by non-conformity in the recycled mix composition.

\section{Analysis of results}

Properties of recycled asphalt greatly depend on properties of material, type of asphalt layer from which it has been obtained, and removal technology. That is why considerable differences may occur between mixes, namely in quality, grain size, and uniformity of composition. Recycled asphalt samples contained different proportions of paving bitumen ranging from $3.16 \%, 5.20 \%, 5.50 \%$ and $6.10 \%$. Such a wide range of proportions made it difficult to design asphalt mix samples. Mix design formulas were determined for the preparation of asphalt mixes of bituminized base/wearing course BNHS-22 with $10 \%, 15 \%$, and $20 \%$ of recycled asphalt in its composition, and with an optimum proportion of paving bitumen 50/70 amounting to $4.90 \%$.

Due to non-uniform composition and an increase in the proportion of recycled mix, deviations occurred in the produced asphalt mixes with respect to the values obtained by laboratory testing. Densities of asphalt mixes varied from 2626 to 2642 $\mathrm{t} / \mathrm{m}^{3}$, while densities of asphalt samples ranged from 2483 to $2525 \mathrm{t} / \mathrm{m}^{3}$. Manufactured asphalt mixes with $15 \%$ and $20 \%$ of recycled material in their composition have a lower percent voids filled with bitumen (69.24\% and $62.50 \%$ ) when compared to [10] where at least 70 percent voids filled with bitumen is specified. The voids content in the asphalt mix with $20 \%$ of recycled material amounts to $6.02 \%$ which is also not compliant with [10] where the max. voids content is limited to $5.0 \%$.
Significant deviations in the recycled asphalt grading were caused by mechanical milling of the existing asphalt course in a single layer. In addition, stone grains from base course of the pavement structure were noticed in the recycled mix. In order to avoid such a non-uniform composition, i.e. to achieve a controlled composition of the recycled asphalt, the milling should be conducted in segments depending on the type of the asphalt layer, and the material obtained in this way should be carefully separated and stockpiled.

At the asphalt plant, the recycled asphalt proportioning was conducted without pre-heating, i.e. by direct proportioning into the mixer. The mineral mix was heated to the temperature of $200-235^{\circ} \mathrm{C}$ (depending on the recycled asphalt content), and the final temperature of the asphalt mix with recycled asphalt was $144-149^{\circ} \mathrm{C}$. During trial production, it was established that a significantly greater moisture content in recycled asphalt also requires a greater mineral mix heating temperature. The recycled asphalt moisture content could be lowered simply by covering the stockpiled material.

\section{Conclusion}

Results of laboratory testing and trial production of asphalt mixes, which contained 10, 15, and 20 percent of recycled asphalt obtained by old asphalt pavement milling, are presented in the paper. The laboratory testing was conducted to determine suitability of recycled asphalt for use in a new asphalt mixtures, and to design the asphalt mix composition of BNHS-22 with various proportions of recycled asphalt. Various design mixes, with different proportions of recycled 
asphalt, were manufactured during trial production in the asphalt base. Some difficulties with production technology, due to recycled asphalt properties, were noted. The following conclusions were made:

- Asphalt mixes with $15 \%$ and $20 \%$ of recycled material in their composition have a lower percent voids filled with bitumen $(69.24 \%$ and $62.50 \%$ ) when compared to General Technical Requirements for Road Works where at least 70 percent voids filled with bitumen is specified.

- In order to avoid a non-uniform composition of the recycled asphalt mix, i.e. to achieve its controlled composition, the milling should be conducted in segments depending on the type of the asphalt layer, and the material obtained in this way should be stockpiled separately.

- At the asphalt plant, the recycled asphalt proportioning was conducted without pre-heating, i.e. by direct proportioning into the mixer. It was established that a significantly greater moisture content in recycled asphalt also requires a greater mineral mix heating temperature. During the recycled asphalt milling, the cutting blades of the milling machine become moist due to reduced temperature, which in turn results in a higher moisture content in the removed material. In addition, the recycled material is exposed to natural elements (precipitation) during stockpiling. The problem of higher moisture content could partly be solved by storing the recycled material in a covered storage area for a sufficiently long time.

- The results obtained show that savings can be made in the production of asphalt mixes. Thus, savings in mineral mix would amount to $11-23 \%$ depending on the proportion of recycled asphalt, while savings in the paving bitumen proportioning would amount to 6-8.5 \%. Due to nonuniformity of the recycled asphalt mix composition, the mentioned savings in paving bitumen are much lower that the planned savings based on laboratory testing.

As already indicated in the introductory part of the paper, the use of recycled asphalt aggregate in new asphalt mixes nowadays ranks among the most widespread uses of construction waste worldwide. The asphalt aggregate has confirmed its usability by many years of continuous use on road construction projects in developed European countries. In the beginning, this material is used on trial sections under real-life conditions, and is then applied as a standard material. European countries with a long-standing tradition in the production of new asphalt mixes have developed technical regulations [11] that define properties of materials, properties of asphalt mixes, methods for determining percentage of recycled asphalt in mixes, and an appropriate construction technology.

In Croatia, the currently applied General Technical Requirements for road Works do not offer possibilities for using the recycled asphalt aggregate (nor any other nonstandard material) in the production of asphalt mixes. However, the situation will be improved after the oncoming publication of new regulations on asphalt mixes. The results described in this paper are a step forward in the study of asphalt mixes containing recycled asphalt aggregate, the principal aim being to gain a fuller insight into properties and behaviour of these mixes.

\section{REFERENCES}

[1] Aničić, D., Čulo, K.: Građevinski inženjeri na putu u Europu, PROJEKT CARDS 2001, Europska unija i Građevinski fakultet Osijek, Osijek, 2004.

[2] Dimter, S., Mogućnost primjene otpadnih materijala u graditeljstvu, Petogodišnji program stručnog usavršavanja u gradevinarstvu, Građevinski fakultet Osijek, 2005-2010.

[3] Schwabe, Ž.: Recikliranje asfaltnih kolničkih konstrukcija, Gospodarenje prometnom infrastrukturom, Dani prometnica 2009, Zagreb, rujan 2009. 189-239.

[4] Roberts, F., Kandhal, P., Brown, E.: Vruće asfaltne mješavine, materijali, projektiranje i ugradnja, drugo izdanje (prijevod s engleskog jezika), Hrvatski savez građevinskih inženjera: Institut građevinarstva Hrvatske, 2003.

[5] HRN EN 12697-2:2003 Bitumenske mješavine - Ispitne metode za asfalt proizveden vrućim postupkom - 2. dio: Određivanje granulometrijskog sastava
[6] HRN EN 12697-1:2003 Bitumenske mješavine - Ispitne metode za asfalt proizveden vrućim postupkom - 1. dio: Topljivi udio veziva

[7] HRN EN 12697-5 Ispitne metode za asfalt proizveden vrućim postupkom - 6. dio: Određivanje gustoće asfaltnih mješavina

[8] HRN EN 12697-6 Ispitne metode za asfalt proizveden vrućim postupkom - 6. dio: Određivanje gustoće asfaltnih uzoraka

[9] HRN EN 12697-8 Ispitne metode za asfalt proizveden vrućim postupkom - 6. dio: Određivanje šupljina u asfaltnim uzorcima,

[10] General Technical Requirements for Road Works, Volume III, Pavement structure, Civil Engineering Institute, Zagreb 2001 (in Croatian)

[11] Sherwood, P.T.: Alternative materials in road construction, A guide to the use of recycled and secondary aggregates, second edition, Thomas Telford Publishing, London, 2003 